\title{
Anisakis sp. dan Alergi yang Diakibatkannya
}

\author{
Robiatul Adawiyah ${ }^{1}$, Esy Maryanti ${ }^{2}$, Forman E.Siagian ${ }^{3}$
}

\begin{abstract}
Parasitic diseases were initially found in many endemic areas, but currently also found in non endemic areas. One is anisakiasis caused by Anisakis sp. Humans can be infected by this parasite by direct consumpt the organism and contact with the fish / products of food that containing this parasite. There are some points that can increase the risk of infection of this parasite, high movement of people from one area to another either temporary or permanent, the food processing especially in the case of the fish packing, the advance of transportation that enables the widespread of marine products which contaminated and how to eat the fish which contaminated. Anisakis sp. Antigen derived from the excretion-secretion products, somatic and cuticular of the parasite larvae. Good hygiene and understanding of the problem and potential risk will increase alertness and awareness of Anisakis sp.infections
\end{abstract}

Keywords: Anisakis sp, anisakiasis, allergy

Banyak jenis parasit yang ada di sekitar kita dapat menyebabkan penyakit, patogen murni ataupun yang oportunistik. Penyakit akibat parasit banyak ditemukan terutama di daerah endemik, namun saat ini dengan tingginya migrasi dan perjalanan antar daerah, bahkan antar negara, mengakibatkan parasit dapat ditemukan menginfeksi manusia di daerah non endemik, yang dikenal dengan penyakit impor. ${ }^{1}$

Cacing dari berbagai spesies merupakan salah satu parasit yang dapat menginfeksi hewan dan manusia. Anisakis sp merupakan cacing kelas nematoda yang menginfeksi ikan atau mamalia, terutama yang berasal dari laut dalam meski beberapa laporan menyebutkan juga sering ditemukan pada ikan air tawar. ${ }^{1-12}$ Meski hospes definitif nya adalah ikan, larva nematoda ini secara insidental juga dapat mengakibatkan penyakit pada manusia (zoonosis) yang mengkonsumsi daging mengandung larva yang tidak dimasak dengan

\footnotetext{
Departemen Parasitologi Fakultas Kedokteran Universitas Indonesia,

2 Bagian Parasitologi Fakultas Kedokteran Universitas Riau,

3 Bagian Parasitologi Fakultas Kedokteran Universitas Kristen Indonesia
}

baik. ${ }^{1,2,8,9}$ Parasitisme oleh larva dan atau cacing dewasa disebut anisakiasis. ${ }^{1,8,9}$

Secara epidemiologis, Anisakis sp. ini penting karena dua hal yaitu, yang pertama parasit ini banyak menginfeksi mamalia laut (singa laut, paus dan lumba-lumba) dan berbagai jenis ikan, terutama yang berasal dari laut dalam, yang sering dikonsumsi oleh manusia. Cara menyiapkan makanan, dalam hal ini bila produk laut yang tercemar larva tidak dimasak hingga matang atau bahkan dimakan mentah (lazim dilakukan dibeberapa negara), memungkinkan larva cacing masih hidup dan dapat menginfeksi manusia. ${ }^{1-3,8,9}$ Disamping itu, kemajuan teknologi bidang pengolahan pangan terutama dalam hal pengalengan ikan dan semakin majunya sistem transportasi memungkinkan meluasnya distribusi atau penyebaran produk laut yang mungkin tercemar Anisakis. ${ }^{1,3,9}$ Artinya, kemungkinan infeksi dapat terjadi didaerah-daerah yang letaknya jauh dari habitat alamiahnya. ${ }^{1-3,10-12}$

Infestasi Anisakis sp pada produk perikanan akan mengurangi nilai ekonomis ikan yang terinfeksi dan dapat menyebabkan beragam gangguan pada manusia. ${ }^{1,3}$ Gejala yang sering ditimbulkan oleh parasit ini saat menginfeksi manusia adalah terutama kelainan pada saluran 
cerna dengan spektrum beragam; bisa berupa hanya keluhan ringan seperti nyeri, mual -muntah, gingivostomatitis, gangguan saluran cerna ringan sampai berat, bahkan pernah dilaporkan menyebabkan obstruksi usus halus yang memerlukan intervensi bedah. ${ }^{1,2,4,5,8,9}$ Selain itu, larva nematoda ini juga dapat menyebabkan reaksi alergi (hipersensitifitas) pada orang yang sensitif., ${ }^{1,2,6}$ Makalah ini bertujuan untuk mengulas mengenai taksonomi, siklus hidup dan gejala klinis berupa alergi yang ditimbulkan oleh cacing nematoda Anisakis sp serta cara produk laut tercemar menyebabkan anisakiasis.

\section{TAKSONOMI DAN SIKLUS HIDUP}

Penelitian mengenai Anisakis banyak dilakukan, terutama dinegara dengan kasus anisakiasis tinggi. Selain itu, tempat-tempat dimana konsumsi ikan laut tinggi atau ikan laut menjadi salah satu produk pangan andalan seperti Jepang, Belanda, Inggris, Spanyol serta negara-negara lain disepanjang pantai Pasifik dan Amerika selatan juga melaporkan hal serupa. ${ }^{1-8}$ Kemajuan teknologi molekuler memungkinkan penempatan Anisakis dalam perspektif taksonomi yang benar sebagai berikut: Kingdom: Animalia, Phylum: Nematoda, Kelas: Secernentea, Ordo: Ascaridida, Family: Anisakidae, Genus: Anisakis (Karl Rudolph 1809)..$^{1,7,8}$

Anisakis and Pseudoterranova, genera yang paling sering dilaporkan menyebabkan penyakit pada manusia,memiliki sejumlah stadium siklus hidup yang dapat ditemukan pada hospes intermediet, paratenik dan definitif. ${ }^{1,3,4,8}$ Hospes definitifnya adalah hewan yang dalam hospes tersebut stadium cacing dewasa bereproduksi secara seksual dan menghasilkan keturunan. Hospes intermediet adalah hewan yang mengandung stadium juvenile parasit (larva) dan memungkinkan parasit untuk dapat berkembang satu atau beberapa kali menjadi bentuk yang lebih matang. Parasit mungkin memiliki beberapa stadium larva, yaitu stadium larva tahap pertama (L1), stadium larva tahap kedua (L2) dan seterusnya. Hospes paratenik berperan dalam keberhasilan proses transfer parasit ke hospes berikutnya, yaitu hospes definitif, yang dalam siklus rantai makanan berada dalam posisi yang lebih tinggi. Pada hospes paratenik, tidak lagi terjadi perkembangan larva. ${ }^{1,7,8}$ Hospes aksidental, seperti manusia, sebenarnya bukan merupakan bagian dari rantai infeksi alamiah Anisakis dan secara normal tidak akan menyebabkan infeksi pada hospes definitif. Hospes aksidental terinfeksi secara tidak sengaja dan menjadi jalan buntu (dead end) bagi siklus hidup cacing. ${ }^{1,8,9}$

Spesies cacing yang saat ini diketahui adalah A. pegreffii, A. physeteris, A.schupakovi, A. simplex, A. typica dan A. ziphidarum. Sedangkan yang dapat menginfeksi manusia adalah Anisakis (Terranova) simplex yang kerap ditemukan pada ikan herring), Pseudoterranova (Phocanema) decipiens yang kerap menginfeksi ikan cod atau anjing laut, Contracaecum spp., dan Hysterothylacium (Thynnascaris) spp. Spesies yang paling sering dilaporkan menginfeksi manusia adalah A. simplex dan P. decipiens. Sejumlah penelitian menggunakan elektroforesis terhadap enzim multilokus menunjukkan morphospecies Anisakis, Contaceum dan Pseudoterranova terdiri atas sekelompok subspecies yang secara genetik telah berdiferensiasi, tergantung lokasi geografis habitatnya serta distribusi hospesnya. ${ }^{7}, 12$

Cacing-cacing tersebut (family Anisakidae dan genera Pseudoterranova, Phocascaris dan Contracaecum) secara bersama-sama lazim disebut anisakid, dapat menginfeksi mammalia laut, burung laut, reptil dan ikan laut dalam (hospes definitif) sedangkan beberapa jenis krustasea lebih sebagai hospes intermediate. Ikan dan juga moluska (terutama jenis gurita) juga dapat berperan sebagai hospes transport yang membawa larva infektif. ${ }^{1}$ Banyak jenis species ikan dapat 'membawa' larva anisakid, termasuk dibagian daging sehingga memungkinkan transmisi infeksi ke predator pemangsa ikan seperti manusia., ${ }^{1,3,4,6-8}$ Meski demikian, rentang jenis hospes yang dapat terinfeksi spesies Anisakid masih belum semuanya terungkap. Lagipula, masih terdapat kontroversi dalam cara transmisi alternatif, misalnya apakah terdapat rute infeksi secara langsung dengan cara ikan terinfeksi setelah 'menelan' larva yang berenang bebas atau misalnya terjadi transfer larva dari krustasea seperti krill ke cetacea omnivorous pemakan plankton tanpa melalui ikan telah diketahui berperan menjadi hospes transport. ${ }^{1}$

Siklus hidup Anisakis sp dapat dilihat pada gambar 1. berikut. 


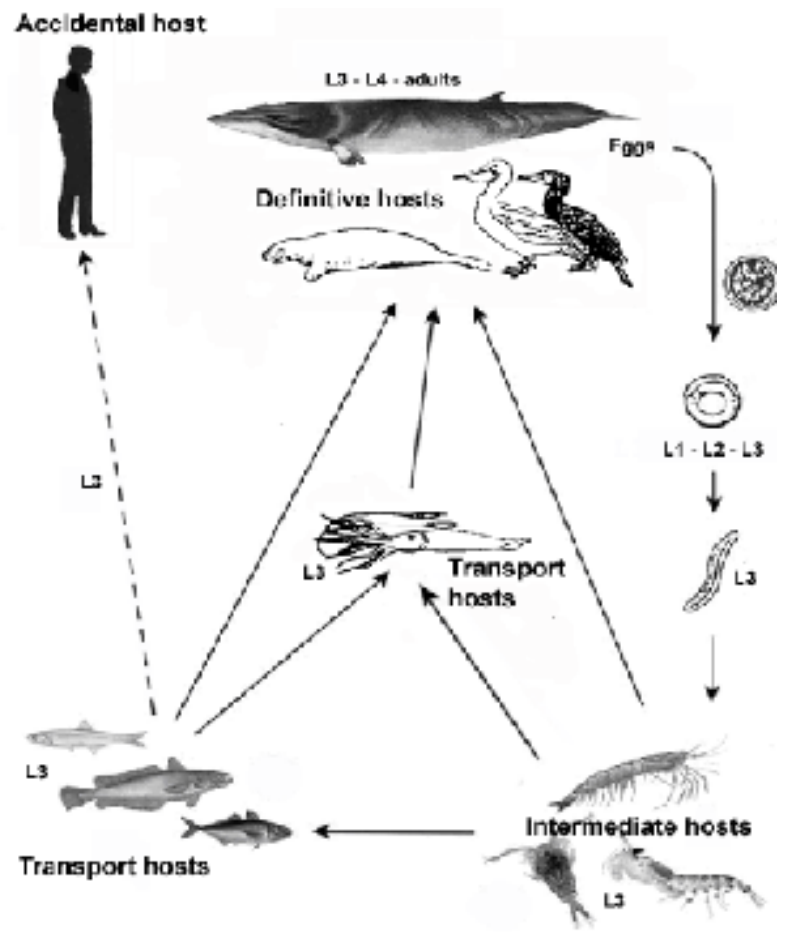

Gambar 1. siklus hidupAnisakis sp1, dengan modifikasi

Sebagai hospes insidental, manusia dapat terinfeksi jika memakan daging ikan atau produk laut yang mengandung larva Anisakis sp. dalam keadaan mentah atau kurang matang. ${ }^{1-3,6}$ Beberapa negara dengan konsumsi ikan laut tinggi seperti Jepang dan Spanyol juga melaporkan tingginya kasus anisakiasis pada manusia, lebih tinggi dibanding negara-negara lain yang konsumsi ikan lautnya kurang..$^{1,3,5,6,8}$

\section{IMPLIKASI KLINIS}

Infeksi cacing pada manusia secara umum biasanya menyebabkan meningkatnya kadar eosinofil dan IgE, kondisi yang mungkin terjadi pada pasien dengan hipersensitivitas type I terhadap sejumlah antigen lain. ${ }^{1-3,6,8}$

Dengan pendekatan molekuler, sejauh ini telah diketahui ada delapan jenis alergen yang dimiliki A. simplex (Ani s 1 sampai Ani s 8 ); yaitu dua jenis diantaranya, Ani s 2 dan Ani s 3, merupakan bagian somatik dan tidak satupun diantara kedelapan alergen tersebut yang berasal dari kutikel. ${ }^{8}$ Ani s 2 dan Ani s 3, merupakan alergen A. simplex yang paling banyak diteliti, termasuk dalam kelas alergen
Paramyosin dan Tropomyosin. Kedua jenis protein tersebut di otot dan kulit banyak jenis invertebrata, diduga menjadi allergen yang poten karena struktur molekuler tropomyosin dibeberapa titik berbeda dengan yang terdapat pada vertebrata sehingga menimbulkan respons alergi yang kuat.$^{1,7,8}$ Hasil penelitian Ramos et al seperti yang dikutip Audicana et al $^{8}$ mengungkapkan Ani s 2 mirip dengan alergen paramyosin tungau debu (Blo t 11, Blomia tropicalis). Kemiripan-kemiripan dalam urutan protein yang highly conserved mungkin menjadi penyebab reaktivasi silang dengan alergen shrimp (Pen a 1) dan tungau debu rumah (Der p 10 dan Der f 10). ${ }^{8}$ Selain itu, ada juga jenis alergen tropomyosin lain (Cha f I) yang struktur nya mirip Ani s 3 dan bersifat tahan panas; kemiripan struktur seperti itu juga mengindikasikan kemampuan termostabil Ani s $3 .^{8}$

Paradoks sekaligus ironi bahwa banyak studi epidemiologi dan eksperimental pada hewan coba menunjukkan infeksi parasit cacing kronis bisa memproteksi atau setidaknya mengurangi reaksi alergi; meskipun ada elemen dasar alergi, reaktivasi klinik justru mengalami down regulation. namun karena larva maupun cacing dewasa anisakid bukan parasit alamiah pada manusia maka tidak akan timbul respons adaptasi yang memadai sehingga sebagai konsekuensi nya juga tidak akan timbul down regulation sistem imun. ${ }^{1}$ Selain itu, karena kemiripan struktur tropomyosin pada invertebrata, antibodi spesifik IgE yang terbentuk terhadap larva Anisakis bisa mengalami reaksi silang (cross react) terutama terhadap alergen yang berasal dari jenis produk laut/sea food lain seperti udang dan tungau debu rumah. ${ }^{1,7,8}$ Karenanya, hasil uji hipersenitivitas mesti diinterpretasi dengan cermat dan hati-hati untuk menghindari kemungkinan salah diagnosis (false positive atau false negative).

\section{Alergi Akibat Anisakis sp: Implikasi Konsumsi Produk Perikanan}

Anisakiasis pada manusia sebenarnya tidak lazim karena parasit itu tidak akan mampu beradaptasi untuk hidup pada manusia dan infeksi yang terjadi sebenarnya bersifat transit semata. ${ }^{8} \mathrm{Hal}$ itu dapat dilihat perbedaannya misalnya antara anisakiasis dengan filariasis atau askariasis, dimana dapat terjadi sejumlah besar cacing berada dalam tubuh orang yang terinfeksi dan sifatnya menetap- 
sehingga dikatakan parasit dan inangnnya telah saling menyesuaikan diri untuk mengoptimasi kelangsungan hidup bersama. Hipersensitivitas sangat jarang terjadi; biasanya kematian parasit secara alamiah atau akibat obat yang justru memicu hipersensitivitas/alergi. ${ }^{8}$.

Alergi merupakan salah satu bentuk pertahanan tubuh yang 'negatif' karena bentuk respons mekanisme pertahanan spesifik yang over-reaktif terhadap substrat allergenik ( bisa berupa molekul non self) yang disebut allergen. Alergen bersifat sebagai antigen pemicu reaksi alergi dan respons imun. Ada empat jenis alergi, tipe I-IV; alergi akibat parasit cacing biasanya berupa hipersensitivitas tipe I (tipe cepat) yang dimediasi oleh antibodi IgE. 1,5,6,8,9

Sejauh ini, A. simplex merupakan produk perikanan yang paling sering dikaitkan dengan respons alergi. Respons alergi yang ditimbulkannya meliputi: yang pertama adalah anisakiasis gastroalergi yang gejala alerginya merupakan gejala tambahan akibat parasitisme akut dilambung setelah memakan ikan atau produk laut lainnya yang mengandung larva hidup secara mentah atau dimasak kurang matang dan yang kedua berupa alergi terhadap A. simplex yang terjadi akibat kontaminasi produk perikanan yang mengandung alergen (larva yang ada pada produk perikanan tersebut tidak mesti hidup). Respon alergi lainnya bisa terjadi, meski lebih jarang ditemukan, berupa urtikaria kronik akibat sensitisasi A, simplex ( mekanisme belum jelas diketahui), asma dan gastroenteritis eosinofia, gejala rheumatologi, dermatologi dan rhino-konjungtivitis. ${ }^{1,5,6,8,9}$

Respons imun akibat anisakiasis meliputi respons imun bawaan (sel epitel terinfeksi, nitric oxide, Toll like receptor) dan didapat (Th2, IL-4, IL-5) serta eosinofilia; eosinofilia merupakan gambaran peradangan lokal pada lesi akibat larva A. simplex (infiltrasi eosinofil disekitar parasit dalam jaringan). Konsentrasi eosinofil didaerah yang sakit tidak hanya akibat pelepasan faktor kemotaktik oleh limfosit T, sel mast dan basofil tetapi juga oleh sekresi substansi kemotaktik oleh parasit. Yang menarik, meski eosinofilia sering dikaitkan dengan infeksi cacing namun untuk anisakiasis hanya ditemukan pada kurang dari $30 \%$ anisakiasis. ${ }^{8,10}$ Meski demikian, infiltrasi eosinofil dijaringan disekitar parasit merupakan gambaran paling khas mengenai lesi inflamasi lokal akibat anisakiasis. ${ }^{8}$

Tabel 1. Ringkasan kronologi patofisiologi infeksi A. simplex pada manusia ${ }^{8}$, dengan modifikasi

\begin{tabular}{|c|c|c|c|}
\hline $\begin{array}{l}\text { Waktu } \\
\text { setelah } \\
\text { konsumsi }\end{array}$ & $\begin{array}{l}\text { Kejadian } \\
\text { patofisiologi }\end{array}$ & $\begin{array}{l}\text { Faktor yang } \\
\text { dilepaskan atau } \\
\text { respons imun yang } \\
\text { terjadi }\end{array}$ & Yang terjadi dijaringan \\
\hline$<1 \mathrm{jam}$ & Perlekatan mukosa & Enzim proteolitik & $\begin{array}{l}\text { Lesi hemorhagik, larva } \\
\text { 'terkubur' dan terbentuk saluran }\end{array}$ \\
\hline 4 jam- 6 hari & $\begin{array}{l}\text { Penetrasi mukosa- } \\
\text { submukosa }\end{array}$ & Faktor kemotaktik & $\begin{array}{l}\text { Phlegmon eosino filik, lesi } \\
\text { erosif }\end{array}$ \\
\hline 7-14 Hari & $\begin{array}{l}\text { Pembentukan } \\
\text { granuloma }\end{array}$ & $\begin{array}{l}\text { Induksi respons } \\
\text { hipersensitivitas }\end{array}$ & Lesi ul seratif \\
\hline$>14$ hari & Kematian larva & $\begin{array}{l}\text { Peradangan persisten } \\
\text { atau terbentuk } \\
\text { granuloma }\end{array}$ & $\begin{array}{l}\text { Hilang nya parasit atau ulserasi } \\
\text { kronis jika parasit menetap/ada } \\
\text { sisa bagian parasit }\end{array}$ \\
\hline
\end{tabular}

Laporan mengenai alergi akibat anisakiasis banyak ditemukan pada beberapa daerah di Spanyol, yaitu pada daerah tersebut konsumsi ikan dalam keadaan mentah lebih tinggi. ${ }^{69}$ Kondisi itu lebih jarang dilaporkan dinegara-negara Eropa lain. Tidak jelas diketahui apakah hal itu disebabkan oleh masih kurangnya pemahaman klinisi mengenai anisakiasis atau belum digunakannya uji diagnostik yang sesuai, 
sehingga kasus-kasus anisakiasis mungkin banyak yang terluput, atau memang terdapat perbedaan insiden penyakit signifikan di Sponyol dibanding negara-negara lain di Eropa. ${ }^{1}$ Di Asia, Jepang merupakan contoh negara dengan konsumsi ikan paling tinggi dan secara bersamaan juga paling sering melaporkan kejadian anisakiasis. ${ }^{1,5,6,8,9}$

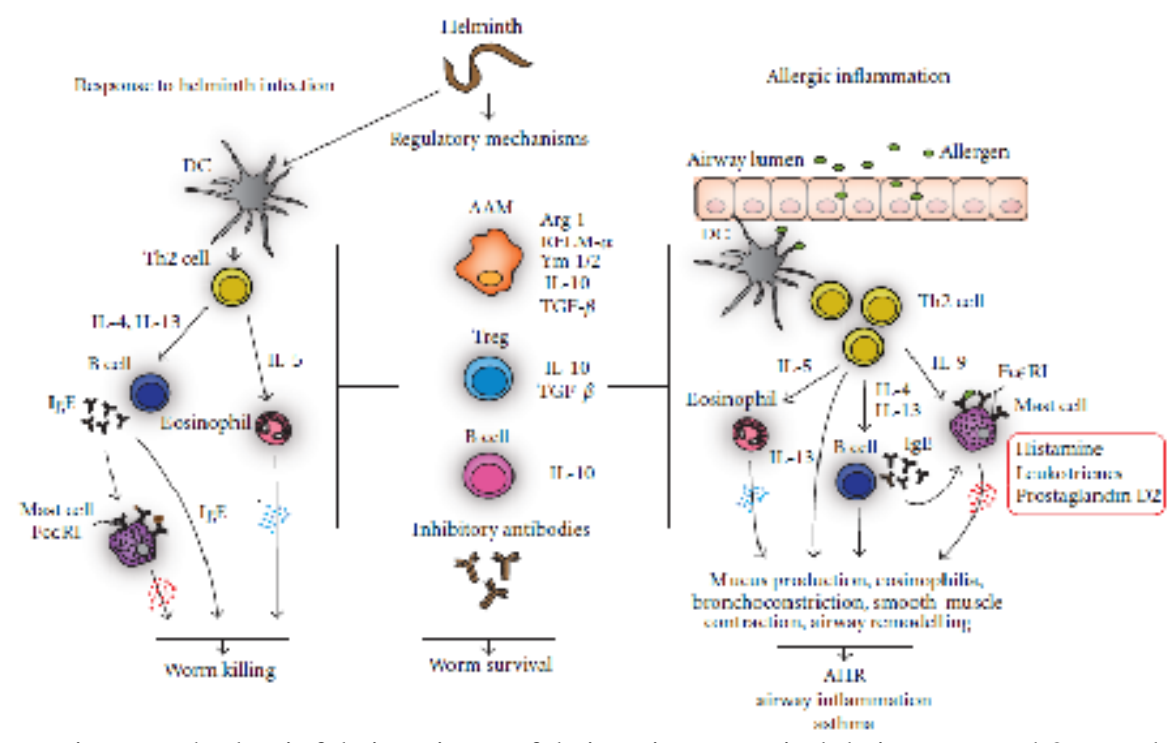

Gambar 2. respons imun terhadap infeksi cacing. Infeksi cacing menginduksi respons Th2 yang bersifat protektif, namun mekanisme pengaturan sistem imun (imunoregulasi) bisa menguntungkan larvae cacing dengan cara memodifikasi respons Th2 dan menghambat proses inflamasi. Namun juga dpat terjadi inflamasi alergi, yang ditandai dengan pelepasan histamin, leukotriene dan prostaglandin yang menimbulkan terbentuknya mukus, eosinofilia, bronkokonstriksi, kontraksi otot polos dan remodelling paru yang mengakibatkan hiperaktivitas saluran nafas, peradangan saluran nafas atau asma. Peradangan alergi bisa ditekan melalui mekanisme imunomodulator akibat infeksi cacing 10 dengan modifikasi

Danilowicz-Luebert et a ${ }^{10}$ mengklasifikasikan alergi akibat Anisakis sp sebagai penyakit okupasi karena dapat juga terjadi akibat kontak tanpa harus mengkonsumsi daging ikan yang tercemar. Hal itu juga didukung oleh hasil penelitian Armentia et al seperti yang dikutip oleh Armentia et al, ${ }^{13}$ Niuwenhuizen et al seperti yang dikutip Audicana et $a l,{ }^{8}$ Scala et $\mathrm{l}^{14}$ serta beberapa peneliti lain seperti yang terdapat pada laporan EFSA Panel on Biological Hazards (BIOHAZ) ${ }^{1}$ pada pekerja pabrik pengolahan ikan dimana terjadi alergi akibat kontak terhadap ikan tercemar larva Anisakis sp atau bersifat okupasional. Infeksi oleh anisakid relatif jarang ditemukan dan bersifat aksidental. ${ }^{8-12}$ biasanya sistem imun yang teraktivasi adalah Th2 ketimbang mekanisme imunomodulator yang lebih sering ditemukan pada infeksi cacing kronik sehingga gejala alergi menjadi lebih menonjol. ${ }^{8-10}$ Respons imun terhadap infeksi cacing tersebut dapat dilihat pada gambar 2 .

\section{Cara Penyebaran Produk Laut Tercemar Anisakis sp}

Globalisasi dan modernisasi teknologi serta derasnya arus informasi memberikan dampak yang luas dalam berbagai aspek kehidupan manusia. Misalnya, perkembangan teknologi informasi memberikan imbas kepada industri gaya hidup seperti kuliner. Pola penyajian makanan yang dulunya hanya dikenal di satu negara, dewasa ini dengan cepat dan mudah dapat ditemukan di negaranegara lain. ${ }^{89}$ Contohnya, makanan Jepang berbasis ikan Sushi; yang kini menjadi trend kuliner yang tidak lagi hanya menjadi kuliner lokal tetapi telah meng-global dan menjadi sangat digemari. . $^{3,5,6,9}$ Selain itu, Teknik pengawetan seperti pengasapan atau pengasinan telah digantikan dengan industri pengalengan yang lebih canggih dan cepat dengan mesin-mesin yang lebih efektif dan efisien untuk kemudian didistribusikan keberbagai negara yang menginginkan. 
Negara-negara dengan pesisir pantai yang luas juga cenderung mengkonsumsi lebih banyak ikan; hal itu juga mendorong kreativitas dalam mengolah ikan atau produk laut lainnya menjadi produk kuliner yang eksotis. ${ }^{1,49}$ Beberapa contoh makanan yang berbasis ikan mentah atau kurang dimasak sampai matang diantaranya sushi dan sashimi (Jepang), bagoong (Filipina), ikan herring asin atau asap (Belanda), gravlax (Skandinavia), lomi-lomi dan palu (Hawai), ceviche (Amerika selatan), boquerones en vinagre/ pickled anchovies (Spanyol). ${ }^{8}$ Metode persiapan jenis makanan tersebut meliputi pengasinan, penambahan asam/ cuka, penambahan bumbu, pengasapan sampai suhu $40^{\circ} \mathrm{C}$, yang secara umum bisa mensterilisasi patogen yang food borne namun belum memadai untuk anisakid. ${ }^{1,3,8}$ Anisakid sendiri mampu menginfeksi beragam jenis ikan dan ditemukan dibanyak tempat didunia. $^{1-14}$

Tabel 2. Hasil penelitian mengenai Anisakis sp pada beberapa spesies ikan yang ditangkap dari beberapa lautan $^{4,9,10-12 \text { dengan modifikasi }}$

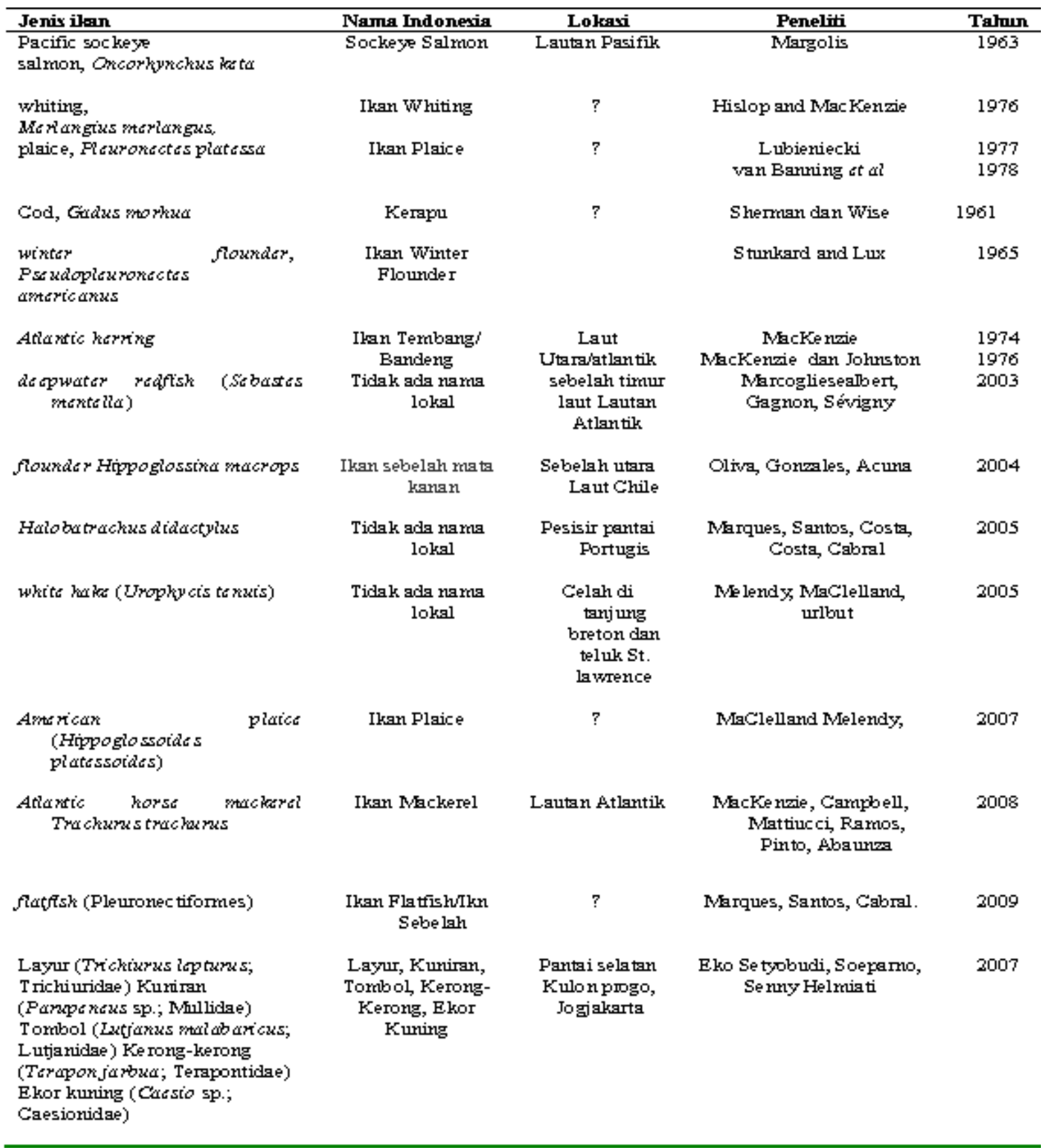


Tidak dapat dipungkiri, aspek pemenuhan akan kebutuhan konsumsi bisa menjadi kekuatan industri suatu negara. Contohnya Jepang, dimana karena konsumsi ikannya yang tinggi maka sektor perikanan menjadi industri yang sangat kuat. Kapalkapal Jepang yang besar dan sudah sangat modern menangkap ikan didaerah yang sangat jauh dari wilayahnya (sehingga kadang-kadang menimbulkan sengketa dengan negara lain yang merasa batas wilayahnya dilanggar )- kemudian ikan yang tertangkap langsung diolah dan dikemas dalam kaleng untuk kemudian siap dipasarkan.

Hal itu telah dinyatakan sebelumnya oleh Sakanari dan McKerrow, seperti yang dikutip Audicana dan Kennedy, ${ }^{8}$ bahwa alasan peningkatan jumlah kasus anisakiasis di Amerika Serikat pada dekade 80 an dan masih relevan sampai sekarang, yaitu (1) akibat distribusi nematoda anisakid yang luas didunia-telah dilaporkan ditemukan dibanyak laut dan lautan utama, (2) meningkatnya populasi mamalia laut- berperan sebagai inang bagi cacing parasit dewasa, (3) meluasnya cakupan migrasi dan globalisasi- dengan salah satu konsekuensinya meningkatnya permintaan akan makanan-makanan eksotis berbasis ikan, (4) makin seringnya digunakan alat-alat masak yang serba instan seperti microwave dan cooker dan keyakinan untuk tidak memasak makanan saampai terlalu matang karena dapat merusak zat gizi dan (5) informasi mengenai manfaat jenis diet berbasis ikan yang diyakini jika banyak dikonsumsi mampu mencegah penyakit jantung.

Faktor lain yang mungkin mempengaruhi intensitas dan pola respons imun terhadap A. simplex adalah sumber dan bentuk imunogen yang mengenai pasien. Secara hipotetis, pajanan terhadap antigen A. simplex bisa berasal dari (1) keseluruhan larva (produk ekskresi-sekresi, somatik dan kutikuler) sebagai akibat penetrasi jaringan dan degenerasi larva- terjadi pajanan terhadap profil komplit antigen parasit, (2) hanya terhadap antigen ekskresi-sekresi misalnya pada kasus larva berhasil dikeluarkan oleh inang dalam keadaan utuh/intak dan (3) antigen kutikuler dan somatik yang berasal dari makanan yang mengandung larva yang sudah mati- sehingga antigen ekskresi-sekresi hanya ada dalam jumlah sedikit. ${ }^{8}$ penelitian Armentia et $a l^{13}$ menguatkan hipotesis tersebut. Kelompok peneliti tersebut meneliti data 231 pasien dengan alergi A. simplex dan menyimpulkan, berdasarkan uji in vivo dan in vitro, penderita yang tersensitasi $A$. simplex dapat mendeteksi alergen parasit yang terkandung dalam daging ayam. ${ }^{8}$

Masalahnya, daging ikan juga digunakan sebagai pakan ternak dibeberapa negara; sehingga jika ikan yang menjadi pakan utama hanya sekedar campuran sekalipun mengandung larva anisakid kemudian dikonsumsi oleh ternak dan kemudian ternak dimakan oleh manusia, maka dengan cara seperti itu pun manusia dapat berisiko tersensitasi oleh alergen yang terdapat dalam daging ternak. . $, 6,8,13$ Hewan ternak yang dimaksud adalah bukan hanya terbatas pada hewan ternak di darat seperti ayam atau unggas lain namun bisa juga ikan hasil budidaya. ${ }^{6,8,13}$

Dalam konteks ikan hasil budidaya, potensi terinfeksi Anisakis sp atau parasit lain dapat terjadi melalui dua cara, yaitu yang pertama jika ikan budidaya dalam proses perkembangbiakannya diberi makan sisa ikan / produk laut yang tidak diproses terlebih dahulu dan yang kedua jika ikan liar yang belum dewasa ditangkap untuk kemudian dibudidaya (dilakukan dipenangkaran ikan kod dan tuna di Eropa); resiko timbul jika ikan liar yang ditangkarkan tersebut telah terinfeksi oleh larva anisakid. Cara yang disebut pertama lebih lazim dilakukan dalam praktek budidaya ikan dilaut. ${ }^{6,8,13}$ Karenanya, praktek hygiene pribadi yang baik memang sangat perlu dilakukan untuk mencegah transmisi anisakiasis.

\section{PENUTUP}

Telah diulas mengenai taksonomi, siklus hidup dan gejala klinis berupa alergi yang ditimbulkan oleh cacing nematoda Anisakis sp serta cara produk laut tercemar menyebabkan anisakiasis. Praktek hygiene yang baik dan pemahaman akan cakupan masalah serta potensi resiko akan meningkatkan kewaspadaan dan kesadaran akan infeksi yang disebabkan A. simplex.

\section{UCAPAN TERIMAKASIH:}

Bpk Aryan Obrien Siagian, Departemen Kelautan dan Perikanan Republik Indonesia atas 
bantuannya dalam mengoreksi nama Latin dan nama Indonesia ikan-ikan yang disebutkan dalam makalah ini

\section{DAFTAR PUSTAKA}

1. EFSA Panel on Biological Hazards (BIOHAZ). Scientific opinion on risk assessment of parasites in fishery products. EFSA journal 2010: 8 (4): 1543

2. Gomez B, Lasa E, Arroabarren E, Garrido S, Anda M, Tabar AI. Allergy to Anisakis simplex.An sis sanit navar. 2003: 26 (S2):25-30

3. Food standard Agency. Guidance concerning wild salmon and the Anisakis parasite. 2007. www. food.gov.uk

4. Setyobudi E, Soeparno, Helmiati S. Infection of Anisakis sp in some marine fishes from the southern coast of Kulon Progo, Yogyakarta. Biodiversitas. 2011: 12 (1):34-7

5. Roland SK, Keeling WB, Gunasekaran S, Shapiro DH. Is it safe to eat sushi? Bowel obstruction related to anisakiasis. Surg Rounds 2008; 31 (3): 105-14

6. Fernandez de Corres L, del Pozo MD, Aizpuru F. Prevalence of Anisakis simplex sensitisation in three Spanish areas, in relation to fish intake rates. Relevance of Anisakis simplex allergy. Allergol immunol clin 2001; 16: 337-46

7. Nadler SA, D'Amelio S, Dailey MD, Paggi L, Siu S, Sakanari JA. Molecular phylogenetics and diagnosis of Anisakis, Pseudoterranova and Contracaecum from northern Pacific marine mammals. J Parasitol. 2005; 91 (6):1413-29
8. Audicana TM, Kennedy MW. Anisakis simplex: from obscure infectious worm to inducer of immune hypersensitivity. Clin Microbiol Rev 2008; 21 (2): 360-79

9. Siagian FE, Siagian GTY, Siagian AO. Kelainan yang berhubungan dengan larva Anisakis sp.. Maj Kedok FKUKI. 2010; 27 (3): 122-9

10.Danilowicz-Luebert E, O’Regan N, Steinfelder S, Hartmann S. Modulation of specific and allergy related immune responses by helminths. J Biomed Biotech 2011. article ID 821578

11.Jurado-Palomo J, Lopez-Serrano MC, Moneo I. Multiple acute parasitization by Anisakis simplex. J Investig allergol clin immunol 2010; 20 (5): 437-41

12. Abollo E, D'Amelio S, Pascual S. Fitness of the marine parasitic nematode Anisakis simplex. str. in the temperate waters of the NE atlantic. Diseases of aquatic organisms. 2001; 45:131-9

13. Armentia A, Martin-Gil FJ, Pascual C, MartinEsteban M, Callejo A, Martinez C. Anisakis simplex allergy after eating chicken meat. $\mathrm{J}$ investig allergol clin immunol 2006; 16 (4): 25863

14. Scala E, Giani M, Pirrotta L, Guerra EC, Cadoni S, Girardelli CR, De Pita O, Puddu P. Occupational generalises urticaria and allergic airborne asthma due to anisakis simplex. Eur J Dermatol 2001; 11 (3): 249-50 